\title{
A csoma-újtelepi késő avar kori temetőrészlet
}

\author{
HARAG MÁTYÁS \\ Eötvös Loránd Tudományegyetem Bölcsészettudományi Kar Régészettudományi Intézet, \\ H-1088 Budapest, Múzeum krt.4/B., e-mail: harag.matyas@gmail.com
}

HARAG, M.: The cemetery of the Late Avar Age in CsomaÚjtelep.

Abstract: The cemetery, which was discovered in the northern territory of Csoma (Somogy County) in 1956, lies in the valley of River Kapos. In this region we know several cemeteries from the Early Middle Ages, but most of them are unpublished. According to the published sites, a large population lived there at the time of the fall of the Avar Khaganate. Future research will be able to answer what happened with this people after the end of the Avar rule. However, the first step in this research is to analyze and publish the unpublished sites, like the Late Avar Age cemetery of Csoma.

Keywords: Early Middle Ages, Kapos-valley, Avar Khaganate

Csoma község Somogy és Tolna megyék határán, de még Somogy megyében (1. ábra), Kaposvártól 22 kilométerre keletre, a 61-es főút mentén helyezkedik el. A község északi részén előkerült avar kori temetőrészletet Pusztai Rezső (1926-2004) tárta fel, aki 1954-1957 között volt a kaposvári Rippl-Rónai Múzeum munkatársa. A feltárásról először az Archaeologiai Értesítő hasábjain számoltak be (BURGER-PATAY 1958, 89.). A csomai temetőrészlet leletanyaga egy ideig a kaposvári állandó régészeti kiállításban is szerepelt. 1964-ben két, Somogy megyei régészeti lelőhelyeket összegyűjtő és falvanként bemutató katasztert adtak ki, amikben a csomai temetörészletet is feltüntették (DRAVECZKYSÁGI-TAKÁTS 1964, 18.; Kocztur 1964, 35.). Bakay Kornél 1973-ban közölte leletanyagának egy részét, közzétéve a temető térképét, és néhány szóban megemlékezett a sírok tartalmáról is (BAKAY 1975, 42-45.). A publikáció nyomán, Garam Éva is írt a csomai ostorvégről (GARAM 1998, 110.; 119.). A sírok antropológiai anyagát Évinger Sándor, Hajdú Tamás és Bernert Zsolt dolgozta fel és jelentette meg a Folia Anthropologica hasábjain (BERNERT-ÉVINGER-HAJDú 2006, 54-55.).

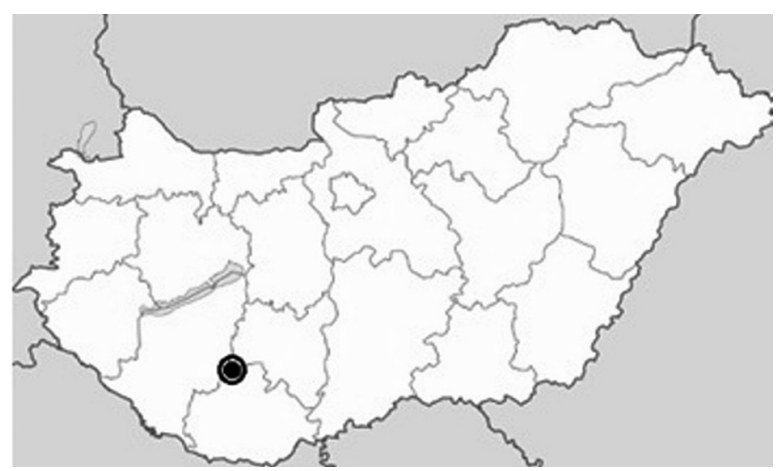

1. ábra. Csoma település elhelyezkedése

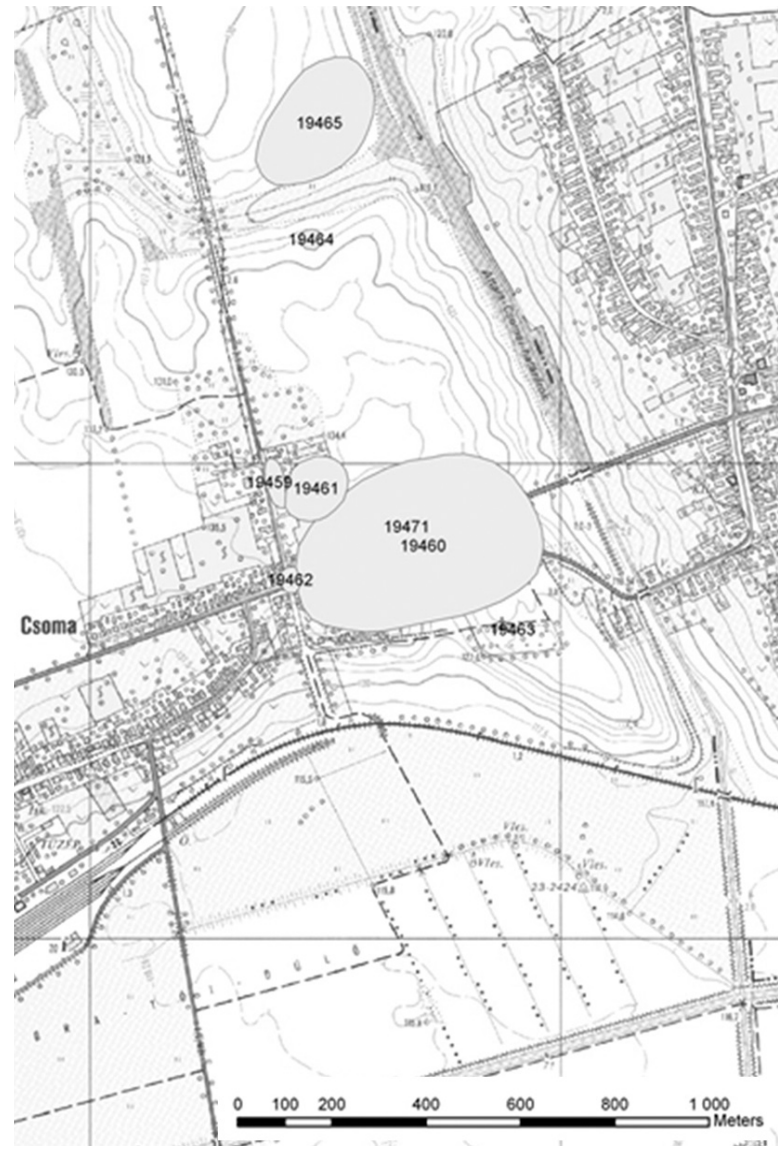

2. ábra. Ismert régészeti lelöhelyek Csoma területén (az avar kori temető a 19459. számú)

A csomai avar kori temető (lelőhelyazonosító: 19459) a község északi részén az Ady Endre utca keleti házsora és azok kertjei alatt húzódik (2. ábra). A temető sírjait (10. ábra) egy, a felszíni nyomok alapján is azonosított, nagyobb kiterjedésű rézkori település nyugati végébe ásták bele, aminek objektumai a temető feltárása során is előkerültek. A leletmentő ásatásra két szakaszban, 1956. június 13-23 között, illetve 1956. augusztus 8-án és 9-én került sor, miután az említett házsor első házainak építésekor (4. ábra), az A1 és A3 agyagkitermelő gödrökben sírok kerültek elő. A munka előbb ezeknek az árkoknak az átvizsgálásával kezdődött. Az Évinger-család telkén lévő A1-es árokban Pusztai öt elpusztult sír helyét (1-5. sír), a Nagy-család telkén lévő A2-es árokban a szintén elpusztított 6 . és 7. sír, valamint egy rézkori temetkezés helyét azonosítot- 


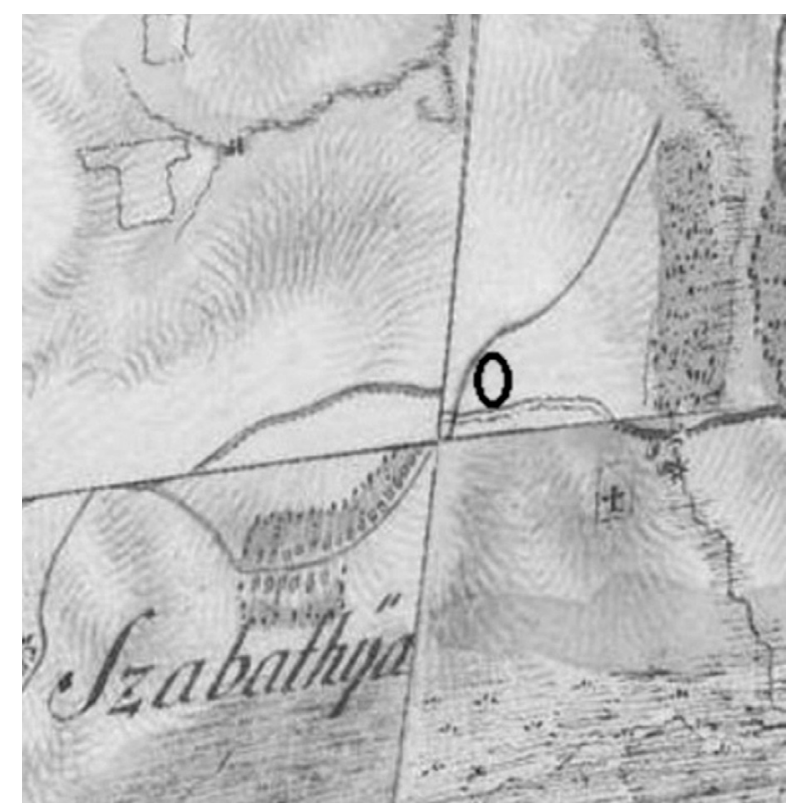

3. ábra. Csoma az I. katonai felmérés térképén (tévesen Szabadiként feltüntetve)

ta, a sírok tájolását és mélységét feljegyezte, valamint összegyűjtötte a munkásoktól az általuk megtalált leleteket. Ugyancsak az A2-es árok délkeleti végében nyílt lehetősége Pusztainak a 8. avar sír, valamint egy rézkori településobjektum (vélhetően egy ház) feltárására, amelybe az említett 8., valamint a 7. sírt is beleásták.

Pusztai ezt követően Nagy Sándor házának keleti falához és az agyagkitermelő árkokhoz igazodva három szelvényt jelölt ki. Az I. szelvény nyugati felében két őskori telepobjektum -egy vélhetően téglalap alakú ház és egy gödör-, továbbá a szelvény délkeleti sarkában, a 9. számú avar sír foltjai rajzolódtak ki. A szelvény feltárása közben fotók is készültek. Az A1es agyagkitermelő ároktól keletre nyitották a II. szelvényt, amelynek nyugati felében több, a rézkori településhez tartozó, lefelé szélesedő cölöplyukat, valamint a 10. számú sír sarkát tárták fel, majd ezt követően bontottak rá a sírra. Az A1-es agyagkitermelő gödör és az I. szelvény között nyitott III. szelvény nyugati felében az I. szelvényben is megfigyelt téglalap alakú rézkori objektum folytatódott, míg a szelvény keleti felében a 11. számú sírt tárták fel.

A lelőhelyen további leletmentésre került sor, miután augusztus 8-án értesítették a múzeumot további sírok megbolygatásáról. A helyszín a korábbi feltárások helyétöl délre, mintegy 55 méter távolságban, a Kosaras-féle telken volt, ahol az újonnan nyitott agyagkitermelő árokban az előzetes munkálatok során két melléklet nélküli sírt (13. és 15. számú sírok) teljesen, egyet (12. számú sír) pedig részlegesen elpusztítottak. Az említett sírok helyéről és tájolásáról a munkások tájékoztatták az ásatót. Pusztai még aznap feltárta a 12. sír déli falban megmaradt, lábfelőli végét, míg a medence környékéről előkerült sírleleteket előzőleg Nagy Ferenc tanuló mentette meg és adta át a helyszínen az ásatónak.
Az árok nyugati felében a 14. számú sír vége rajzolódott ki, amit másnap, augusztus 9-én feltárt. A sír az elpusztult 13. és 15 . sírhoz hasonlatosan $\mathrm{Ny}-\mathrm{K}$ irányban feküdt.

A sírok leírásához Pusztai a korban elterjedt csontvázlapokat használta, továbbá öt darab fénykép készült a csomai temetörészlet feltárásakor. A képeken a 9. sír feltárás közben két képen szerepel (5-6. ábra), egy képen pedig a 11. sír foltja (9. ábra) is látható. A feltárt 9. sírról két fotó készült, mindegyik az I. szelvény délkeleti sarkáról, de az egyik fotó tükrözve van (7-8. ábra). Hogy ugyanarról a két sírról van szó, a halott bokáján keresztbefektetett állatborda és a láb mellett fekvő állati combcsont tanúskodik.

A temető méretére vonatkozóan kevés adatunk van, de valószínü, hogy Csomán egy nagyobb kiterjedésű, akár több száz síros avar kori temető részleteit tárhatták fel. Erre utalna, hogy a két feltárt sírcsoport között mintegy 55 méter távolság van (10. ábra). Az északabbi sírok esetében, a nyugat illetve kelet felé meghosszabbított szelvényekből további sírok nem kerültek elő, északon azonban a temető folytatódhat, és akár az egykori majorság területére is kiterjedhetett. Pusztai ugyanis hallott arról, hogy ettől a sírcsoporttól északra még az ásatás előtt évekkel, egy olyan sír került elő, amely mélységből és irányításából ítélve az avar temetőhöz tartozhatott. Csallány Dezső egy állítólagosan Csomáról előkerült szórvány kengyelt is ismert a kaposvári múzeum gyűjteményéből, amiröl azonban semmilyen további információ nincs (Csallány 1963, 34.). A délebbre fekvő sírok esetében a temetőszélen való elhelyezkedés nem merült fel. Tudomásom szerint, a sírcsoporttól délnyugatra (4. ábra, fehér négyzettel jelölve) az ásatás után évekkel, vízvezetékek lefektetésekor megbolygattak egy feltehetően a temetöhöz tartozó temetkezést. ${ }^{1}$

\section{Sírleírások ${ }^{2}$}

1-5. sír (I. tábla): A sírokat még Pusztai Rezső kiérkezése előtt elpusztították, anyaguk összekeveredett. Az agyagkitermelő gödör oldalában megmaradt sírvégek alapján tájolásuk É-D-i; mélységüket az ásató átalagosan 200 cm-nek írja. Legalább két adultus korú férfi (30-40 évesek) maradványai vannak az Embertani Tárban.

Mellékletek: 1. Vaskés, középső nyélállású (h.: 12 cm, ph.: $10 \mathrm{~cm}$, psz.: 1,2 cm). 2. vaskés, középső nyélállású (h.: $17,5 \mathrm{~cm}$, ph.: $13 \mathrm{~cm}$, psz.: $1,9 \mathrm{~cm}$ ). 3. Töredékes vaskés, középső nyélállású ( $h .: 8,4 \mathrm{~cm}$, ph.: $6,8 \mathrm{~cm}$, psz.: 1,4 cm). 4. Világosszürke-világosbarna,

1 Az információt köszönöm Dr. Révész László régésznek, volt csomai lakosnak.

2 A kaposvári Rippl-Rónai Múzeum régészeti gyűjteményében a csomai temetörészlet anyaga az 56.16.1.-56.16.7. valamint 56.40.1.-56.46.1. leltári számok alatt (a temető anyagához hozzátartozik egy leltári szám nélküli vaskés is) található. Rövidítések: t.: Tájolás. sm.: sírmélység, sh.: sírhosszúság; ssz: sírszélesség, ma.: magasság, h.: hosszúság, sz.: szélesség, á.: átmérő, pá. peremátmérő, há.:hasi átmérő, tá.: talpátmérő, ph.: pengehossz, psz.: pengeszélesség, v.: vastagság. 
apró kavicsokkal soványított, lassú korongon készült, nagyméretü, tojásdad alakú fazék. Az edény pereme erősen kihajló és ferdén levágott. Vállát és hasát párhuzamosan körbe futó vonalak díszítik. Kiegészített. (Ma.: $16 \mathrm{~cm}$, pá.: 12,7 cm, há.: $15 \mathrm{~cm}$, tá: $9 \mathrm{~cm}$ ).

6. sír (I. tábla): Nő. T.: É-D, sm.: $210 \mathrm{~cm}$, sh.: ismeretlen, ssz.: ismeretlen. A sírt teljesen elpusztították.

Mellékletek: 1. A koponya mellett fülbevaló. Aranyozott ezüstből készült, karikája kerek, hatszög átmetszetü és felforrasztott gyöngydróttal díszített. Merev tengelyes szerkezetű csüngője granulátumokból és egy nagy, tömör ezüstgömbből áll (á.: 2,9×2,7 cm, v.: 0,3cm). 2 . A lábak között szürkés-vöröses foltos, csillámos homokkal soványított, lassú korongon készült fazék. Pereme erősen kihajló és lekerekített, körben körömbenyomkodással díszített. Alján talpgyürü nyomai. Kiegészített. (Ma.: 13,7 cm, pá.: 11,1 cm, há.:12,5 cm, tá.: 7,9×7 cm).

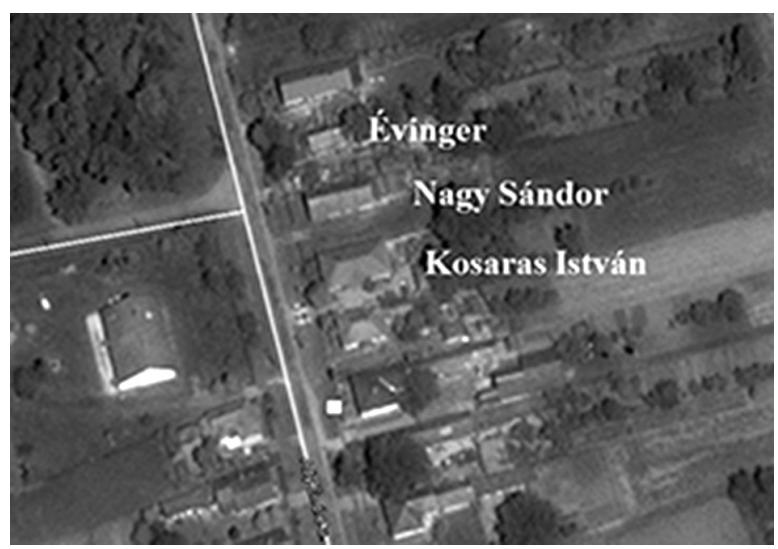

4. ábra. Müholdfelvétel a lelöhelyről

(Google Earth, 2015.06.06.)

7. sír (II. tábla): Nő. T.: ÉNy-DK, sm.: $230 \mathrm{~cm}$. sh.: ismeretlen, ssz.: ismeretlen. A sírt teljesen elpusztították.

Mellékletek: 1. A fejnél ovális alakú, rombusz átmetszetü, zöld üveggyöngy csüngővel ellátott fülbevaló került elő (á.: 2,3×1,7 cm, v.: 0,3cm), az üveggyöngy elkallódott. 2. A nyakon gyöngysor: 40 db dinnyemag alakú gyöngy. Áttetsző, világoskék, kék és fekete színűek. Formájukat tekintve lapos cseppszerüek, olykor mindkét oldalon bordával vagy benyomva; kör- vagy téglalap átmetszetű, kúposak. $62 \mathrm{db}$ áttetsző, fekete, szürkésfekete, szürke kásagyöngy; 3 db fekete korong alakú gyöngy; $3 \mathrm{db}$ selejtes gyöngy; $3 \mathrm{db}$ áttetsző és fekete lapított gömb alakú gyöngy; 2 db többtagú rúdgyöngy; $1 \mathrm{db}$ fekete, henger alakú, sárga dudoros gyöngy; $1 \mathrm{db}$ fekete, félgömb alakú gyöngy; $1 \mathrm{db}$ szegment gyöngy töredéke; $1 \mathrm{db}$ áttetsző-fekete üveganyagú gyöngy $1 \mathrm{db}$ áttetsző henger alakú gyöngy. 3 . Az egyik kézfejen állítólag gyürü volt.

8. sír (I. tábla): Gyermek. T.: É-D, sm.: $180 \mathrm{~cm}$, sh.: 180, ssz.: $50 \mathrm{~cm}$. Bolygatatlan, nyújtott testhelyzetü gyermek sírja, a csontozat szinte teljesen elporladt. A váz fölötti rétegben mészszerű anyag nyomai, ugyanebből az anyagból egy nagyobb kupacnyira való a bal lábfejnél.
Mellékletek: 1. A jobb kézfejnél vaskés $(\mathrm{h} .: 7,1 \mathrm{~cm}$, ph.: 3,5 cm, psz.: 1,9 cm) hegyével a lábfej felé. Középső nyélállású, markolatának vége meghajlított. 2. A medencén vasláncvért (?) maradványai összerozsdásodva ( $h$ : $3,5 \mathrm{~cm}$, sz:: $1,2 \mathrm{~cm}, \mathrm{~m} .: 2,6 \mathrm{~cm})$.

9. sír (III. tábla): Férfi, adultus (25-30 éves). T.: ÉNyDK (335-155²), sm.: $240 \mathrm{~cm}$, sh.: $230 \mathrm{~cm}$, ssz.: 70 $\mathrm{cm}$. Bolygatatlan. Nyújtott testhelyzetű férfi sírja, koponyája kissé jobbra dőlt. A sír a fej és a lábak felőli végeken lemélyített, közvetlenül a váz fölötti rétegben mészszerủ anyag nyomait figyeltek meg.

Mellékletek: A medence körül az övhöz tartozó leletek: 1. bronz kisszíjvég a jobb alkaron. (h.: $4,5 \mathrm{~cm}$, sz.: $1,5 \mathrm{~cm}$, v.: $0,5 \mathrm{~cm}$ ). Egylapos, S-alakú indával és áttöréssel díszített, tokos végében három nittszeg. 2 . A szíjvég egy kis szögletes vaslemez fölött feküdt, ez elkallódott. 3-5. $3 \mathrm{db}$ áttört liliomos mellékszíjveret,

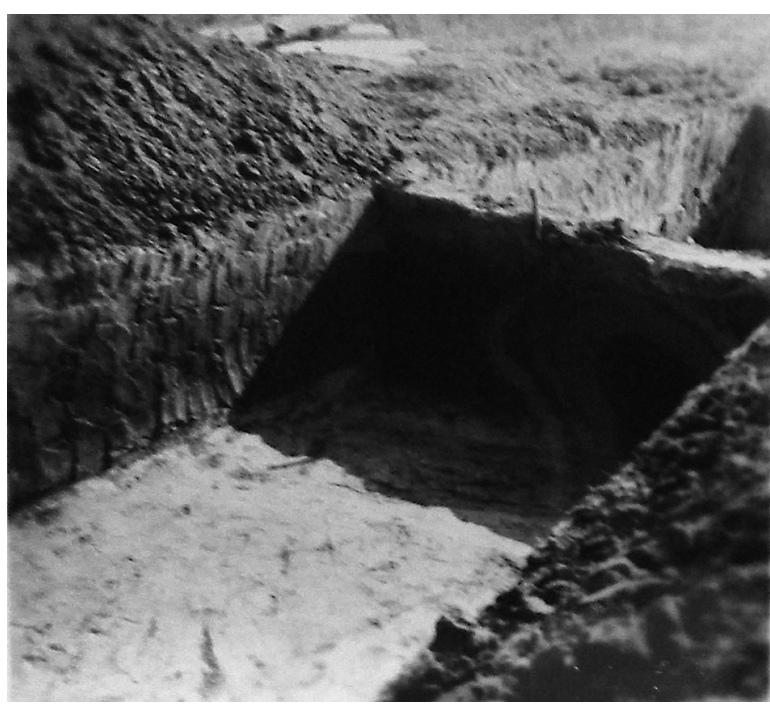

5. ábra. A 9. sír elszíneződése

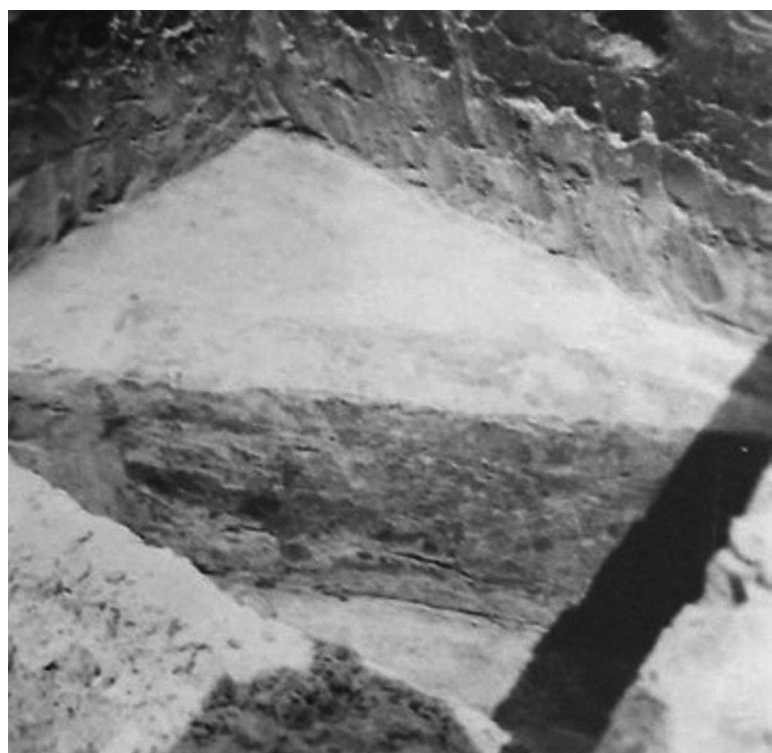

6. ábra. A 9. sír feltárása 


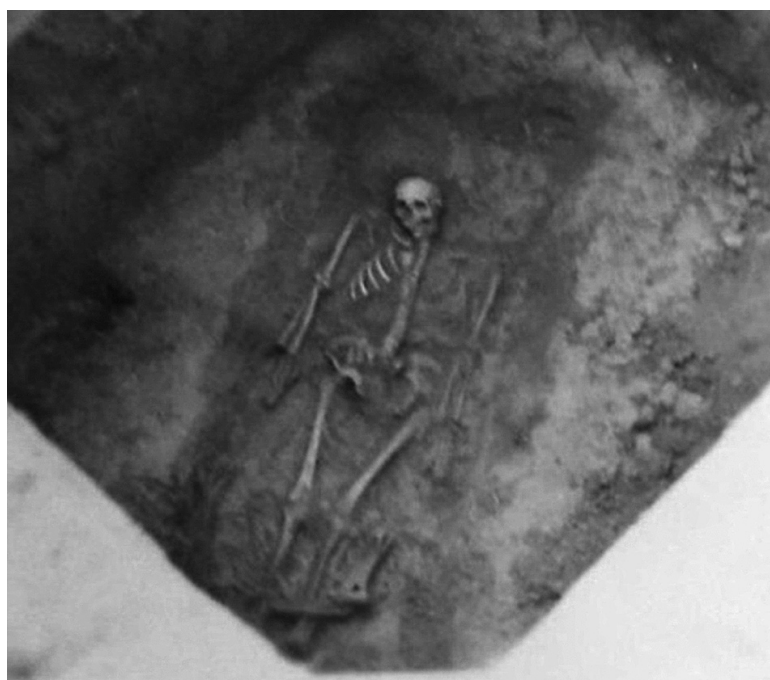

7. ábra. A feltárt 9. sírról készült fotó

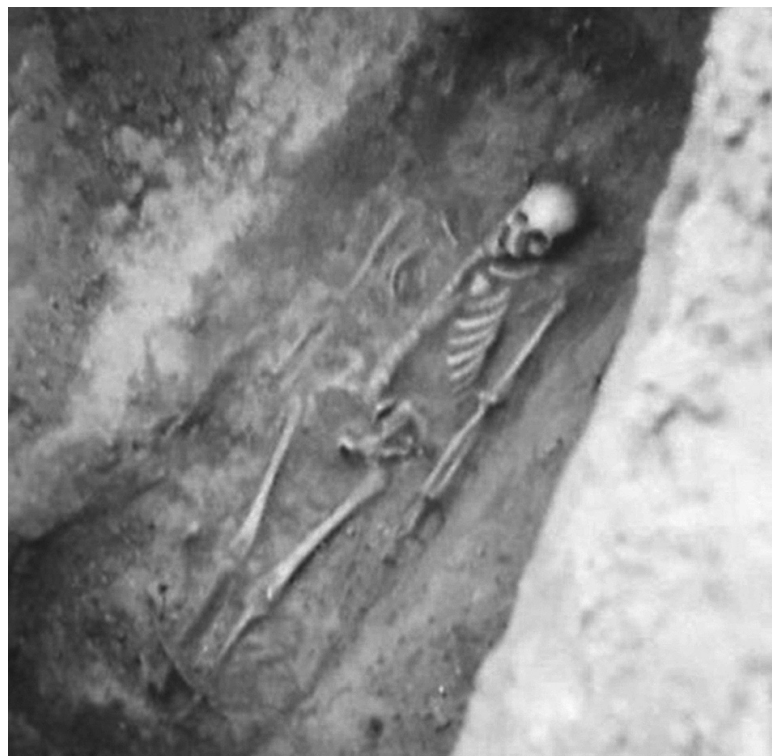

8. ábra. A feltárt 9. sírról készült tükrözött fotó

kettő a jobb alkar és a jobb medencelapát között, egy a jobb medencelapáton, a kisszíjvég vonalában ( $h$.: $1,6 \mathrm{~cm}$, sz.: $1,4 \mathrm{~cm}$, v.: 0,2 cm). 6 . A jobb medencelapáton kisméretü, négyszögletes vascsat (á.: 2,9×2,6 $\mathrm{cm}$ ). 7. Több kisebb, laposfejü bronzszeg (h.: 1,5 $\mathrm{mm}$ ). 8. Közvetlenül a vascsat mellett, a bal oldalon áttört, liliomos övforgó (h.: $7 \mathrm{~cm}$, sz:: 1,4 cm, v.:0,2 $\mathrm{cm}$ ). 9-10. A bal medencelapáton egy kerek vascsat (á.:3,3×3 cm, v.: 0,3 cm) és egy sérült vaskarika (á.: $3,4 \mathrm{~cm}$ ) volt. 11. A jobb kézfejnél hegyével a lábfej felé egy nagyobb vaskés (h.: 16,2 cm, ph.:15,5 cm, psz.: $1,5 \mathrm{~cm}$ ) volt. Töredékes, felső nyélállású. 12. A jobb lábfejnél egy eldőlt, fekete-vörös foltos, csillámos homokkal soványított, kézzel formált és utánkorongolt kisméretű fazék vagy bögre. Pereme lekerekített, enyhén kihajló, alja egyenes. (Ma.: $9 \mathrm{~cm}$, pá: $9 \mathrm{~cm}$, há.:
$9,3 \mathrm{~cm}$, tá.: $6 \mathrm{~cm})$. 13. A bal lábfejnél hasonló edény volt, de nem lehetett megmenteni. 13. A két bögre között esztergályozott ostorvég (h.: $8 \mathrm{~cm}$, á.: $4 \mathrm{~cm}$ ). Agancsból készült, tojásdad alakú. Sérült, bordázott nyakában vasmaradvány, illetve kerek furat. 14 . A jobb combcsont belső oldalán juh vagy kecske lapockája. 15. A bal alsó lábszál külső oldalán feltehetően szarvasmarha combcsontja. 16. A bokákon keresztbefektetve feltehetően szarvasmarha bordája. 17. A jobb oldali bögre szája előtt csirkecsontok voltak.

10. sír (II. tábla): Férfi, adultus (30-40 éves). T.: ÉNyDK, sm.: $170 \mathrm{~cm}$, sh.: $220 \mathrm{~cm}$, ssz.: $60 \mathrm{~cm}$. Bolygatatlan. Nyújtott testhelyzetű férfi sírja, koponyája és jobb alkarja enyhén elmozdult. A koponya alatt a sír lemélyített volt, a nyakcsigolyák alatt faszénmaradványok, a váz fölötti földben mészszerủ anyagdarabok.

Mellékletek: 1. A jobb medencelapáton kisméretű vascsat (á.: 2,9×2,8 cm, v.: 0,2 cm). 2. A bal alkar külső oldalán, hegyével a lábfej felé vaskés (h.: $9,5 \mathrm{~cm}$, ph.: $6,7 \mathrm{~cm}$, psz.: 1,1 cm). Középső nyélállású, lekerekített hegyü.

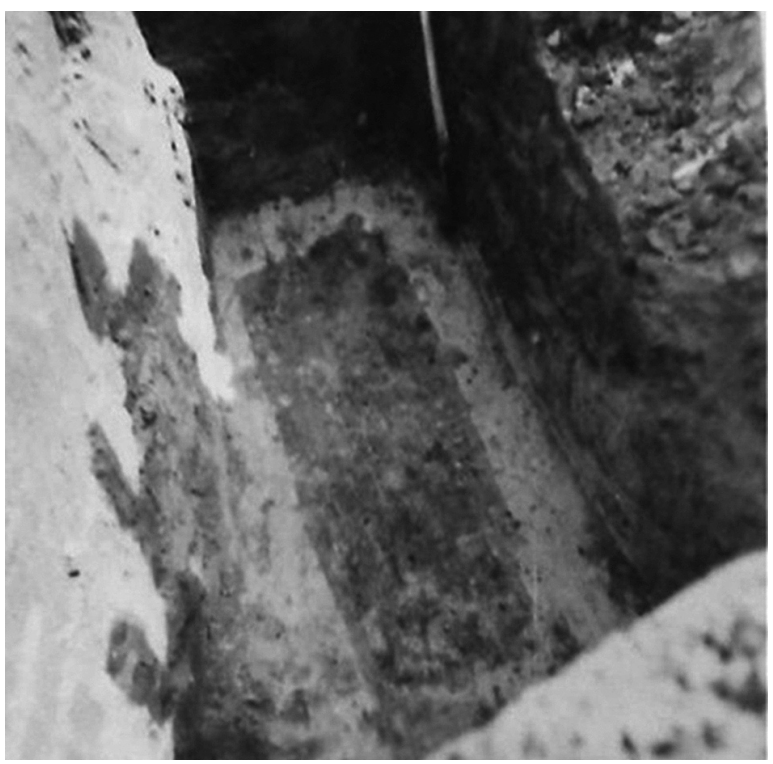

9. ábra. A 10. sír sírfoltja

11. sír (II. tábla): Gyermek, juvenis (15-16 éves). T.: ÉNy-DK (332-152), sm.: $290 \mathrm{~cm}$, sh.: $200 \mathrm{~cm}$, ssz:: $60 \mathrm{~cm}$. Bolygatatlan. Hanyattfekvő serdülő rossz megtartású és hiányos csontváza. A váz feletti földben mészszerü anyagdarabkák.

Mellékletek: 1. A medencelapátok között vascsat (á.: $3 \times 3,1 \mathrm{~cm}$ ) szövetlenyomattal, feltehetően vasszíjvég és a bőrszíj maradványával. 2. A jobb kézfejnél hegyével a lábfej felé vaskés $(\mathrm{h} .: 12 \mathrm{~cm}$, ph.: $9 \mathrm{~cm}$, psz.: 1,6 cm). Középső nyélállású, pengéjén a fa késtok csekély maradványával. 3. A csat mellett, a bal medencénél vastöredékek közül csak egy található meg a leltári anyagban (h.: 2,5 cm, sz: $1,8 \mathrm{~cm}$, v.: $0,2 \mathrm{~cm}$ ). Két rétegből áll, ép sarka lekerekített. 
12. sír (II. tábla): Nő, adultus (20-30 éves). T.: megközelítőleg É-D, sm.: $120 \mathrm{~cm}$, sh.: kb. $200 \mathrm{~cm}$, ssz.: $60 \mathrm{~cm}$. Közvetlenül a feltárás előtt megbolygatott sír, csak a láb felöli vég volt bolygatatlan. A leleteket Nagy Ferenc mentette meg.

Mellékletek: A medence tájékán 1. vascsat (á.: $3 \mathrm{~cm}$ ). Töredékes. 2. Vaskés (h.: $6 \mathrm{~cm}$, ph.: $4,5 \mathrm{~cm}$, psz.: 1,2 cm). Töredékes, felső nyélállású. 2. Nyílhegy (h.: $5,8 \mathrm{~cm}$, sz.: $2 \mathrm{~cm}$ ). Töredékes (tüskéje hiányzik), háromélü. 4 . Vasár (h.: $6 \mathrm{~cm}$, v.: $0,5 \mathrm{~cm})$. Sem a sírleírásban, sem az ásatási naplóban nem szerepel.

13. sír: Meghatározhatatlan nemü. $\mathrm{T}$.: feltehetően Ny-K, sm.: kb. 200 cm, sh.: ismeretlen, ssz.: ismeretlen. Teljesen elpusztított sír, csupán a koponya töredékeit sikerült megmenteni. Leletanyag nem került elő.

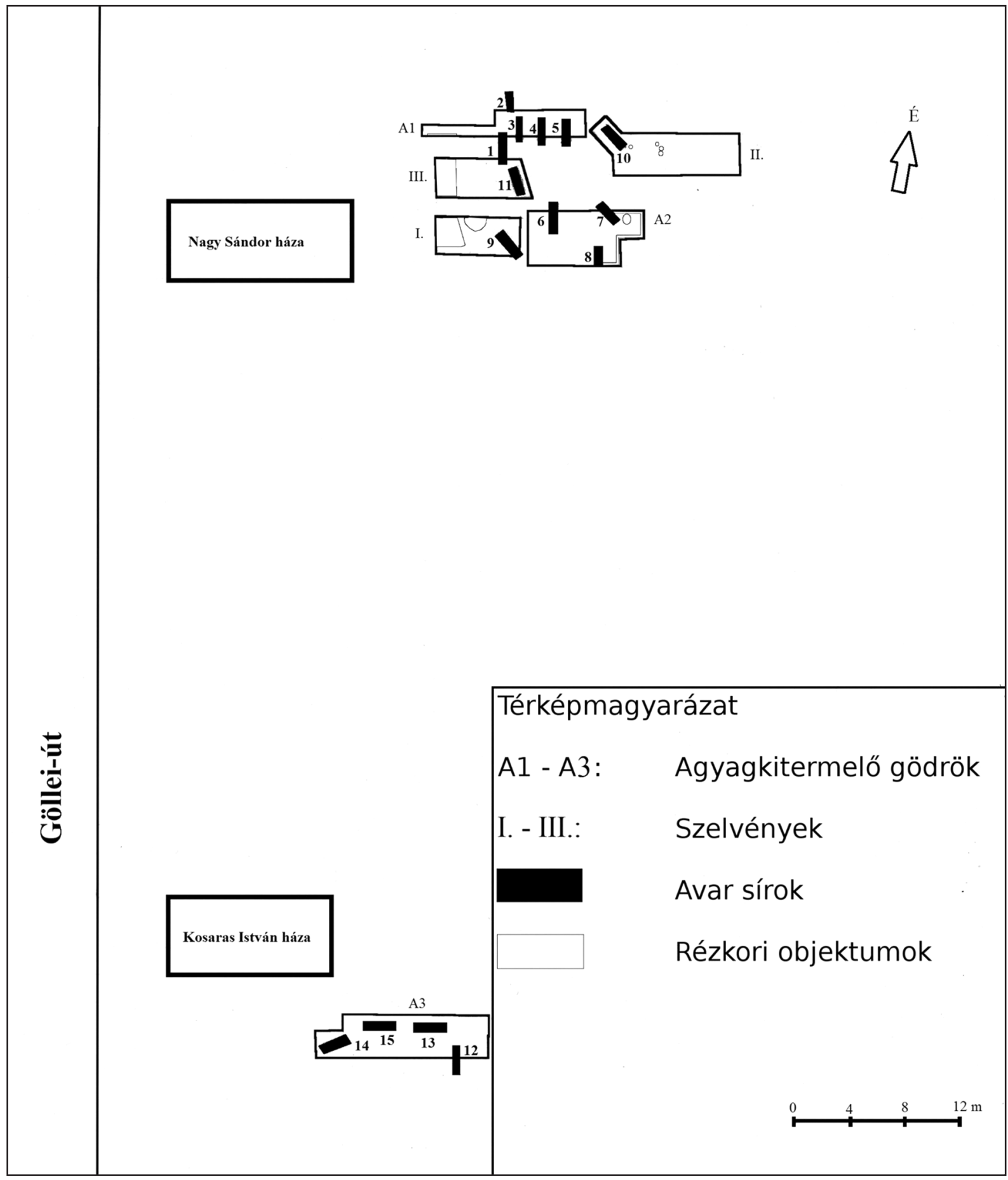

10. ábra. A csomai temetőrészlet térképe 
14. sír (II. tábla): Nő, adultus (30-35 éves). T.: NyDNyKÉK, sm.: $250 \mathrm{~cm}$, sh.: $215 \mathrm{~cm}$, ssz.: $65 \mathrm{~cm}$. Bolygatatlan, nyújtott testhelyzetü nő sírja. A sírgödör a koponya alatt lemélyített, ezért a koponya elmozdult, bal oldalára fordulva, a váz szintjénél $20 \mathrm{~cm}$-rel mélyebben került elő. Jobb karja enyhén behajlítva a medencére téve, bal karja a test mellett nyújtva. A fej fölött és alatt nagy mennyiségű mészszerủ anyaggal vegyes hamut és faszenet találtak, illetve mészszerű anyagdarabkákat figyeltek meg a lábaknál is.

Mellékletek: 1. A jobb csecsnyúlványnál patinanyom mutatkozott, a baloldali a járomíven is. Egyetlen fülbevaló került elő, ovális, csüngő nélküli (elkallódott). 2. A bal csukló mellett bikónikus, sötétszürke, díszítetlen orsógomb (á.: $4 \mathrm{~cm}, \mathrm{~m} .: 2 \mathrm{~cm}$ ). 3. A bal lábszár külső oldalán feltehetően szarvasmarha csigolyája és bordája. 4. Ugyanitt, a lábfejhez közelebb két szárnyas csontváza (csirke és lúd?).

15. sír: Meghatározhatatlan nemü. $\mathrm{T}$.: feltehetően Ny-K, sm.: kb. 200 cm, sh.: ismeretlen, ssz.: ismeretlen. Teljesen elpusztított sír. Leletanyag nem került elő.

\section{Temetkezési szokások}

\section{A temetőrészlet földrajzi elhelyezkedése}

A Kapos-völgye nyugat-keleti irányú somogyi szakasza két kistáj, a völgyet délről határoló Zselici dombvidék és a számos patakvölggyel szabdalt, lankás Külső-Somogy találkozásánál fekszik. Az avar kori temető a Kapos-völgy bal (északi) oldalán helyezkedik el, körülbelül 20 méterrel magasabban és mintegy 500 méterre a Kapos egykor mocsaras, mára azonban kiszárított és szántóföldként hasznosított árterétől. A lelőhelytől északra és keletre folyó patakvölgyektől is hasonló távolság és mintegy 10 méternyi szintkülönbség választja el. A temető tehát magaslaton, vízmentes területen helyezkedett el (3. ábra). A temetöhöz tartozó települést egyelöre nem sikerült a felszíni nyomok alapján azonosítani.

\section{A sírok tájolása}

A temető északi részén több Ny-K-i irányú sírsor rajzolódik ki. Ennek a sírcsoportnak a sírjai a bemérések és a térkép adatai szerint megközelítőleg É-D-i és ÉNy-DK-i tájolásúak, illetve ez utóbbi tengelytől északnak térnek el. A délebbi részen feltárt sírok közül a 12. sír megközelítőleg É-D-i tájolású, a 13., 14. és 15. sírok a Ny-K-i tengelyhez illeszkedhettek, bár csak a 14. sírról vannak adataink (NyDNy-KÉK). Az avar kor kései szakaszában a sírok tájolása igencsak változatos és sokszínü, akár egy régión belül is (TOMKA 1975, 63-64). Az eddig publikált Kapos-völgyi temetörészletekben az uralkodó irányítás a megfigyelt $\mathrm{Ny}-\mathrm{K}-\mathrm{i}$ (Melhárd 1904, 241.; Bárdos 1978, 29.).

\section{A sírok formája, mélysége és méretei}

Az ásatási dokumentációban csak a 9. sír formájáról tettek említést, ami a leírás szerint téglalap alakú, szögletes sarkú aknasír volt. Feltehetően az összes többi temetkezés is hasonló lehetett. A temetörészletben a síroknak mai felszíntől mért, átlagos mélysége 200-210 cm között mozog, a legsekélyebb sírt 120 $\mathrm{cm}$ mélyen (12. sír), a legmélyebb sírt $290 \mathrm{~cm}$ mélyen (11. sír) találták. A temetőrészlet mélyebb sírjai között találjuk a bronz övvereteket is tartalmazó 9. sírt is. A sírok hosszúságáról és szélességéről jóval kevesebb adat áll rendelkezésünkre, ugyanis a bolygatott vagy elpusztított sírok esetében is csak a sírmélységet tudták feljegyezni. A sírok átlagos szélessége 60-61 $\mathrm{cm}$, átlagos hosszúságuk $207-208 \mathrm{~cm}$ körül mozog. A legnagyobb méretű sír a bronz övvereteket is tartalmazó 9. sír a maga 3,86 $\mathrm{m}^{3}$-vel, míg a legkisebb sír a 12. sír, a maga $1,44 \mathrm{~m}^{3}$-vel.

\section{A sírok bolygatása}

A csomai temető esetében mindkét sírcsoport első sírjait löszkitermelés közben pusztították el. A feltárt sírok esetében az ásató nem figyelt meg sírrablásra utaló rablóaknákat, a maradványokat is háborítatlanul találta a sírgödrökben, tehát bolygatatlan temetkezéseket tártak fel.

\section{Koporsóhasználatra utaló nyomok}

A temetőrészlet egyik sírjából sem kerültek elő koporsóhoz tartozó vasalások. Két esetben (10. és 14. sírok) a sírokban, a csontvázak fölött és alatt faszenes-hamus rétegeket is megfigyeltek, amelyhez hasonló jelenségeket többek között már Török Gyula is koporsómaradványokként értékelte (TöRÖK 1973, 9.). Ugyancsak koporsó jelenlétére lehet következtetni a csontok és a leletek elmozdulásából is, ha a bolygatás nyomait nem lehet felfedezni (ToMKA 1977-78, 48-49.; 51-52.). A 9., 10. és 11. sírok kapcsán jegyezték fel a koponya elmozdulását, a 10. sír esetében pedig rajzon jelölik a jobb alkar rendellenes helyzetét. Mindezek azonban csak jelentéktelen elmozdulások a 14. sírban megfigyeltekhez képest, ahol a koponya a váztól távolabb került elő, a 9. sírban pedig az edények oldalukra dőlve kerültek elő. A sírok végeiben megfigyelt lemélyítések (9.; 10. és 14. sírok) is koporsó meglétével hozhatóak összefüggésbe (TOMKA 1978, 52-53). A sírokban a csontvázak fölött megfigyelt és egy esetben (8. sír) a halott lábánál talált kisebb kupacnyi mészszerü anyagról nem jelenthetjük ki biztosan, hogy a koporsó maradványa, mivel nem rendelkezünk anyagmintával.

\section{A halottak sírba helyezésének módja}

A csomai temetőrészletben kivétel nélkül, csontvázas (korhasztásos) temetkezéseket tártak fel. A halottakat a hátukon fekve, kinyújtva helyezték sírba. Az elhunytak kezei jobbára a test mellett, nyújtva feküdtek (8., 9., 11. sír), míg a 14. sírban a halott jobb kezét a medencére helyezték. A 10. sír esetében a bal kéz a test mellett volt, de a jobb alkarcsontok bomlás közben a koporsó üregében vagy állatjárásnak köszönhetően elmozdulhattak. 


\section{A leletanyag értékelése}

\section{Fülbevalók}

A csomai temetőrészletben három sír (6., 7. és 14. sírok) tartalmaz fülbevalót, sajnos azonban a 14 . sír fülbevalója elkallódott. Az antropológiai vizsgálatra (14. sír), illetve a kíséröleletekre (7. sír, gyöngysor, gyưrü?) hivatkozva elmondhatjuk, hogy a fülbevalók javarészt női sírokból származhattak. Noha mindegyik példány magában került elő, fontos megjegyezni, hogy a 6 . és 7 . sírok fülbevalói eleve feldúlt sírokból származnak, illetve a 14. sír esetében a bal járomíven megfigyelhető elszíneződés utalhat a fülbevaló egykori párjára. A 14. sír fülbevalója az ásató leírása szerint a 7. sírból előkerült példányra hasonlíthatott. Utóbbi az ovális, rombusz átmetszetü, gyöngycsüngős fülbevalók közé tartozik, Čilinská X. típusába (ČILINSKÁ 1975, 79.), amely típusnak különböző altípusait, variánsait a kutatás egységesen a késő avar korra, azon belül a 8 . század második felére és a 9 . század elejére keltezi. Ugyan a 7. sír fülbevalójáról elveszett az üveggyöngycsüngő, de megmaradt a karika alsó ívére hajlított vékony, lapos bronzlemez, amelyre felhúzták a gyöngyöt, majd a gyöngy lecsúszását meggátolandó, nyitott végét mindkét oldalon visszahajtották. Az üveggyöngycsüngők ily módon való rögzítéséhez hasonlót a leobersdorfi temető 91. sírjának fülbevalójánál is megfigyelhetünk (DAIM, 1987, 249.; Taf. 92). Az előbb tárgyalt, meglehetősen gyakori fülbevalótípus mellett egy igen ritka típus is előkerült a csomai temetőrészletből. A 6. sír fülbevalójának kerek, négyszög átmetszetű, granulátumokkal díszített karikája, és merevtengelyes, ezüstgömbböl és granulátumokból álló csüngője van. A szokatlan kialakítás miatt a fülbevalót Zlata Čilinská egyik típusába sem sorolhatjuk be, bár kétségtelen, hogy karikájának tulajdonságai és feltehetően az üveggyöngycsüngőket utánzó ezüstgömb miatt a Čilinská-féle IX. típus $A$ variánsához (ČILINSKÁ 1975, 77-79.) állhat a legközelebb. A probléma a keltezésben is megnyilvánul. Míg az említett típust a 7 . század második felére - 8 . század elejére lehet keltezni (ČILINSKÁ 1975, 80.; Abb. 6.), addig a csomai fülbevaló legjobb párhuzamát jelentő, ezüstlemez-gömbös csüngővel ellátott, Zsebes/šebastovce-i temető 79. sírjából előkerült fülbevalót (BUDINSKÝKRIČKA-TOČIK 1991, 21.; Taf. VIII.) a többtagú rúd-; és szegmentgyöngyökből álló gyöngysor a 8-9. század fordulójára - 9. század elejére keltezheti.

\section{Gyöngyök}

Gyöngysor a csomai temetőrészletben egyetlen sírból, az elpusztult 7. női sírból került elő. A közel 100 $\mathrm{db}$ gyöngyből álló gyöngyanyag legnagyobb részét az apró, fekete, ritkábban átlátszó üvegből készült és bronz füzőhengerrel ellátott köles-, félgömb-, hengeres-, bikónikus és lapított gömb alakú gyöngyök teszik ki. Viszonylag nagy számban találhatóak meg a dinynyemag alakú gyöngyök különböző formájú és színü típusai, amelyek közül néhány, mint például a kör átmetszetű, kúpszerü, a mindkét oldalán bordás nyújtott cseppszerü, illetve az általánosabb cseppszerủ típusok megtalálhatóak a székkutas-kápolnadülői temető gyöngysoraiban is (PÁszToR 2003, 364.; 7. táblázat). A gyöngyanyag részét képezi további két szem többtagú rúdgyöngy, egy szegmentgyöngy, egy sárga dudorokkal díszített szemesgyöngy, továbbá egy selejtes gyöngy is. Keltezés szempontjából föleg a dinnyemag alakú és a többtagú rúd alakú gyöngyöknek van jelentősége. Noha a római s bizánci előzményekre visszavezethető dinnyemag alakú gyöngyök már a 7 . század második felétől kezdve előfordulnak az avar kori sírokban, igazi divatjuk a 8. századra esik, és az avar kor végéig megtalálhatóak a temetők leletanyagában (SzŐKE 1992, 873-874.). A többtagú rúdgyöngyök azonban főleg a 8-9. század fordulóján és a 9. Század első harmadában terjednek el tömegesen egész Európában így a Kárpát-medencében is (SzŐKE 1992, 876-879.). Előállításuk a Közel-Keleten folyhatott (GREIFF-NALLBANI 2008, 367-368.). A fentiek alapján, a csomai gyöngysor a 8. század végén, illetve a 8-9. század fordulóján kerülhetett sírba.

\section{Övviselet}

A csomai temetőrészlet négy sírjából került elő övre utaló vascsat (9., 10., 11. és 12. sírok). Egy esetben (9. sír) két vascsat került elő a sírból: míg az egyik a veretes övet foghatta össze, a másik pedig egy veret nélküli öv csatja lehetett. Övre utaló csat szinte csak férfi- ill. fiúsírból ismert, kivételt jelent azonban a 12 . sír, amelynek halottját az antropológiai vizsgálat nőnek határozta meg. Egyedül a temetőrészlet 9. sírjából kerültek elő bronz övveretek, amelyeken ún. liliomos díszítés figyelhető meg. A csomai övvereteken lévő liliomábrázolás (rügyekből kinövő, egymásnak forduló és a középső szirommal összekötött háromszirmú liliompárok a veret középső tengelyének vonalában) Magdalena Schmid tipológiájában az I. típus jellemzője, amely díszítés a késő avar kor kezdetétől a korszak végéig feltünik az övvereteken (ScHMID 2015, 66.; 104.). Míg az övforgó a lekerekített, háromszirmú liliomot ábrázoló és díszítetlen peremủ (Ala típus/ kategória) propellerveretek közé, addig a mellékszíj-, vagy lyukvédő veretek a címer alakú, háromszirmú liliomot ábrázoló, enyhén „pikkelyszerűen” kiképzett szélü (Alb típus/kategória) darabok közé tartoznak (Schmid 2015, 69.; Tab. 11-13.; Abb. 22.). Az I. típust a már a Szalontai Csaba által is körvonalazott (SzALONTAI 1995, 129.; 1. térkép) dél-dunántúli fémművességi körben is gyárthatták, aminek perifériáján helyezkedhetett el a Kapos-völgye (ScHMID 2015, 103-104.). Szalontai Csabának a különböző övveret kombinációkra épülő szeriációs táblázata szerint a tokos, indadíszes kisszíjvég igen ritka kísérőlelete a liliomos övdíszeknek, együttes előfordulásuk föleg a liliomos övgarnitúrák használatának korábbi szakaszára jellemző (SzALONTAI 1995, 129.; 1. táblázat). A csomai övkészlethez hasonló kombinációkat Magdalena Schmidt az Spa I-II idejére keltezi (ScHmID 2015, 90.; Abb. 24.). A csomai övet hiányos övnek kell tartanunk, ugyanis az egyes övszerelékek hiánya eb- 
ben az esetben nem magyarázható a sírrablással. Itt kell megemlítenünk Szalontai Csaba azon megfigyelését, hogy a liliomos övdíszek gyakran hiányos övgarnitúra részeiként, vagy sokszor más készletekbe tartozó veretek társaságában kerülnek elő (SzALONTAI 2003, 396.). E megfigyelést a csomai övgarnitúra is megerősíti. A kisméretű övcsatot figyelembe véve elképzelhető, hogy a kisszíjvéget használtak fel nagyszíjvég gyanánt és ebben az esetben a többi címer alakú veret is lyukvédőként a szíjvég mögé lehetett felerősítve. A már említettek alapján az övveretek a 8. század első felében vagy a század közepén kerülhettek sírba. A többi sírból a már említett egyszerű vascsattal záródó övek (10., 11. és 12. sírok) ismertek. A 11. sír övéhez egy vaskarika is tartozott, amelyen szövetmaradványok maradtak meg. László Gyula szerint e vaskarikának az eszközök, de leginkább a késnek övre való felfüggesztésében lehetett szerepe (László 1940, 95.; 2. kép), amit a díszövek, így a 9. sír esetében is az övforgó láthatott el (LÁszLó 1941, 179.; XLVI. t. 2). Ugyanakkor a László Gyula féle rekonstrukció problémáira újabban Szőke Béla Miklós mutatott rá (SzőKE 2008, 197-201.). A 10. sír esetében hiányoznak az előbb említett függesztők, így elképzelhető, hogy a késtokot csak egyszerű szíjkapcsolással akasztották az övre. További érdekes nyomokat őrzött meg a 11. sír vascsatja, amelyen a textillenyomaton kívül egy kisméretű vas szíjvég tokos vége és a belécsatlakozó bőr maradványa őrződött meg.

\section{Fegyvermelléklet}

A csomai temetőrészletből mindössze a 12. női sírból előkerült töredékes, háromélü nyílhegyet tarthatjuk fegyvernek, illetve talán a hosszabb vaskéseknek is lehetett ilyen funkciója. A nyílhegy Michal Holeščák tipológiájában a BII1-es típusba tartozik, azaz a háromélü, könnycsepp alakú, nyéltüskés nyílhegyek típusába, amely az avar kori temetőkben igen gyakori (HOLEŠčÁK 2015, 304.).

\section{Vaskések}

A csomai temetőrészlet anyagában összesen nyolc vaskés szerepel, sírbeli helyzetét azonban csak négynek ismerjük (8., 9., 10. és 11. sír). Mindannyiszor a test középső részén, a kéz és medencék környékén kerültek elő, a kisalföldi temetőkben megfigyeltekhez hasonlóan általában a halott jobb oldalán (TOMKA 1972, 72.). Az egyetlen kivételt a 10. sír jelenti, ahol a vaskést a halott bal oldalára, az alkar mellé helyezték. A késeket olykor feltehetően az övre függesztve, máskor az övről leoldva helyezték sírba, de hegyük minden esetben a lábak felé nézett. A kés elsősorban a férfi és (fiú?)gyermek sírok jellemző melléklete, egy esetben (12. sír) került elő kés antropológiailag nőnek meghatározott halott sírjából. A legfiatalabb halott, akit késsel temettek el, a 8. sírban nyugvó gyerek volt. Egyben ő rendelkezett a legrövidebb, mondhatni "gyermekméretū" ép késsel $(H .:$ 7,1 cm, P.h.: $3,5 \mathrm{~cm}$, P.sz.: $1,9 \mathrm{~cm}$ ). A csomai temetőrészletből ismert kések többségére jellemző a keskeny és hosszú, valamint egyélü és egyenes hátú penge, nyelük a fogóvégen rendszerint elkeskenyedik. A késpenge a nyélhez legtöbbször középen kapcsolódik, de felső nyélállás is megfigyelhető egyes darabokon (9 és 12. sír). Két esetben (8. és 10. sírok) a kés hegye lekerekített volt, az összes többi esetben hegyes. A 8. sír késmarkolatának végét úgy tűnik meghajlították, talán azért, hogy az esetlegesen fából készült markolatot ne lehessen lehúzni a vasról.

\section{Orsógomb}

A csomai temetőrészlet 14. sírjában nyugvó nő bal oldaláról egy díszítetlen, szürkére égett, apró kaviccsal soványított bikónikus orsógomb került elő. Az orsógombok gyakori sírmellékletek, főleg a későbbi periódusra jellemzőek. Ugyanakkor a dunaújvárosi telep feldolgozása kapcsán már Bóna István is rámutatott, hogy orsógombok a kora avar kortól kezdve előfordulnak a sírok és a telepek leletanyagában (BóNA 1973, 79.). A későbbi, hullámvonallal díszített darabok közé tartozik a közeli kapospulai temető 7. sírjából előkerült példány is (GARAM 1971, 99-100.). A csomai példány elég jellegtelen, keltezése bizonytalan.

\section{Ostorvég}

Már Erdélyi István rámutatott arra, hogy esztergával készültek azok az avar kori gömb vagy tojásdad alakú csonttárgyak (ERDÉLYı 1956, 49.), amelyeket ő is és később Garam Éva is ostor vagy korbácsvégeknek, illetve ostorbuzogányoknak határozott meg (GARAM 1998, 109.), többek közt Bakay Kornél ellenében, aki László Gyula nyomán jogarnak tartotta a 9. sírból előkerült példányt (BAKAY 1975, 43.). A csomai darabot agancsból esztergálták tojás alakúvá. Nyakában vasmaradvány található, amely talán egy hurkos végű vaspálcának a nyomát őrzi, a tárgy hosszúságában futó furattal együtt. A csomai példány formáját tekintve legközelebbi párhuzama a keszthelyi darab, Garam Éva mindkettőt a legkésőbbi avar kori példányoknak tartotta (GARAM 1998, 119.). Nem mellékes az sem, hogy az ostorvég olyan sírból származik, amelynek mellékelt állatcsontanyaga a legváltozatosabb lehetett a temetőrészletben.

\section{Egyéb vastárgyak}

Több csomai sírból is került elő olyan vastárgy, amelyeknek funkciója, meghatározása is bizonytalan. A 8. gyermeksírban talált kisméretü, összeoxidálódott vastárgyon, apró kerek vasgyürük ismerhetőek fel, így jobb híján elképzelhetőnek tartom, hogy láncpáncélból kialakított amulett. A láncingek részleteinek sírba helyezése a környéken a késő avar kori (BÁRDOs 1978, 17.) és a 9. századi (BÁRDos 1985, 14.) temetőkben is megfigyelhető. A 11. sír halottjának jobb combcsontján vastöredékeket talált az ásató, amelyekböl mindössze csak egy darab, egyik oldalán íves, réteges vaslemez maradt meg. Azonosításuk, szerepük bizonytalan, akárcsak azé az elkallódott vaslemezé, amelyik a 9. sírban találtak a kisszíjvég alatt.

\section{Kerámiák}

A temetőrészletből összesen négy darab edény került elő, de múzeumba csak három jutott, ugyanis a 9 . sír egyik kerámiája olyan rossz megtartású volt, hogy megmenteni nem lehetett. Sírbéli helyzetét csak a 6 . 
és 9. sírban lelt edényeknek ismerjük. Előbbi a combcsontok közül, utóbbiak pedig, oldalukra dőlve a lábfejeknél kerültek elő. Esetleges tartamukra vonatkozóan nincs adatunk. A kerámiák közül fazéknak határozhatjuk meg az első öt sír valamelyikéből előkerült és a 6 . sírban talált edényt, míg a 9. sír kerámiáját, méreteit figyelembe véve, Bajkai Rozália nyomán inkább kisfazéknak vagy bögrének tarthatjuk (BAJKAI 2014, 40.). Az ásatási napló szerint a 9. sír másik, fel nem szedett kerámiája is inkább utóbbi csoportba tartozhatott. A nagy fazekak töredékesek, egyes részeiket restaurátornak kellett kiegészítenie, míg a 9. sír edénye viszonylag épp állapotban maradt meg. Mindkét fazék lassan forgó fazekaskorongon készült, míg a 9. sír bögréjét kézzel formálták, esetlegesen utánkorongolták. A kerámiák felszínén lehetőségünk van a soványítóanyagot is megfigyelni, ezek a szórvány fazék esetében apró kavicsok, a 6. sír fazeka és a 9. sír bögréjének esetében pedig csillám vagy csillámos homok. Az edények vörösesbarnaszükésfekete foltossága utalhat arra, hogy az edények feltehetően szabályozatlan körülmények között lettek kiégetve (HEROLD 2004, 20.). A fazekak alját kiegészítették ugyan, de a 6 . sír edényének egy aljtöredékén a körbefutó talpgyürü maradványát is meg lehetett megfigyelni. A 9. sír bögréjének alja egyenes. A szórvány fazék vállát és hasát többé-kevésbé párhuzamosan körbefutó vonalakkal díszítették, a 6 . sír edényének a peremén körben körömbenyomkodás látható.

\section{Állatcsontok}

Állatcsontok a temetőrészlet két sírjából kerültek elő (9. és 14. sír), a deréktól lefelé, a lábak tájékán. A 9. sír halottjának bokáira keresztbe fektettek állatbordát, amihez hasonló jelenséget a Madaras-téglavetői avar temetőben is megfigyeltek (RÁcz 1999, 348). $\mathrm{Az}$ archeozoológiai anyag elveszett, így az állatcsontok meghatározásánál egyedül az ásató megállapításaira hagyatkozhatunk. A bordákhoz (9. és 14. sírok), combcsonthoz (9. sír) lapockához (9. sír) értékes hús tapad, így ezekre ételmellékletként tekinthetünk (VöRös 1999, 54.), a kárcsak a 9. sír csirkecsontjaira is, de a 14. sír egész szárnyasaira már inkább temetési áldozatként. A sírba helyezett lapocka az ásató szerint kecskéé vagy juhé lehetett, míg bordák és combcsont feltehetően szarvasmarhához tartoztak. Utóbbi mellett szól az is, hogy ló combcsont ritkán kerül ételmellékletként sírba (VöRös 1999, 54.). A 14. sír szárnyasai közül a kisebb csontváz tyúké, a nagyobb lúdé lehetett.

\section{Összegzés}

Az elmondottak alapján kétségtelen, hogy mindkét sírcsoport egy nagyobb kiterjedésű avar kori temetőhöz tartozik. Az északabbra fekvő sírokat a leletanyag alapján a 8. század első fele és a 8-9. század fordulója között áshatták, tehát nagyjából ugyanabban az időszakban, mint a Kapospula területén (GARAM 1971, 100-102.) és a toponári temetőhöz tartozó 33. lelőhelyen (BÁRDOs 1978, 42-43.) feltárt temetkezések egy részét. Noha a délebbi sírcsoport esetében pontosabb datálásra nincs lehetőség, a sírok vélhetően késő avar koriak. A Kapos-folyó völgyében, föleg annak somogyi szakaszán több késő avar kori temetőt illetve temetőrészletet is ismerünk, köztük olyanokat is, amelyekben a 9. század elejére keltezhető leletek is megtalálhatóak (SzŐKE 1992, 895.; 897.). További kutatások deríthetnek majd fényt arra, hogy a 9. század elejének történései mennyiben befolyásolták a helyi népesség életét. Ebből a szempontból igen nagy jelentősége van annak is, hogy a Dunántúl legdélebbi, bizonyíthatóan Karoling-kori temetője Kaposvár határában került elő (BÁRDOS 1985, 18.). 


\section{Irodalom}

BAJKAI R. 2014: Késő avar kori település Hajdúnánás határában (Late Avar-age settlement on the fringe of Hajdúnánás). - A Debreceni Déri Múzeum Évkönyve 85: 29-60.

BAKAY K. 1975: Kaposvár földjének őstörténete a legrégibb időktől a honfoglalásig. - In: Kanyar J. (Szerk.): Kaposvár. Várostörténet tanulmányok. Kaposvár, 1975. 11-62.

BÁRDos E. 1978: Avar temető Kaposvár határában (Rescue excavation on the findspot Nr. 33 of Kaposvár). - Somogyi Múzeumok Közleményei 3: 13-65.

BÁRDos E. 1985: IX. századi temető Kaposvár határában (Cemetery of the 9th century in the vicinity of Kaposvár). - Somogyi Múzeumok Közleményei 7: 5-46.

BERNERT Zs., Évinger S. és HAJdú T. 2006: További adatok Somogy megye embertanához. - Folia Anthropologica 4: 53-68.

BóNA I. 1971: VII. századi avar települések és Árpád-kori magyar falu Dunaújvárosban (Awarische Siedlungen aus dem 7. Jahrhundert und ein ungarisches Dorf aus der Árpádenzeit (11-13. Jh.) in Dunaújváros). Budapest

Burger, Sz. A. \& PATAY, P. 1958: Archäologische Forschungen im Jahre 1956. - Archaeologiai Értesítő 85: 79-95.

ČILINSKÁ, Z. 1975: Frauenschmuck aus dem 7.-8. Jahrhundert im Karpatenbecken. - Slovenská Archeológia XXIII: 63-96.

CSALLÁNY D. 1963: A kutrugur-bolgárok(-hunok) régészeti hagyatékának meghatározása (Die Bestimmung der archäologischen Hinterlassenschaft der Kutrugur-Bulgaren (-Hunnen)). - Archaeologiai Értesítö 90: 21-38.

DraveczKy B., SÁGI K. és TAKáTs Gy. 1964: A Somogy Megyei Múzeumok régészeti adattára. Somogyi Múzeumok 2. Kaposvár

ERDÉLYI I. 1956: Az avarkori csontmegmunkálás néhány kérdéséről (o некотор вопросах обработки кости у аваров). - Archaeologia Értesítő 83: 46-50.

GARAM É. 1971: Későavar sírok Kapospuláról (Spätawarische Gräber aus Kapospula). - Folia Archaeologica 22: 97-103.

GARAM É. 1998: Avar kori csont ostor vagy korbácsvégek és ostorbuzogányok (Awarenzeitliche Knochenpeitschen- oder Karbatschenden und Peitschenkeulen). - Communicationes Archaeologicae Hungariae 1998: 109-121.

HEROLD H. 2004: Die frühmittelalterliche Siedlung von Örménykút 54. - Varia archaeologia XIV. Budapest

HOLEŠČAK, M. 2015: Early medieval arrowheads from the area of todays Slovakia. In: Calin Cosma (eds.): Warriors, weapons, and the harness from the $5^{\text {th }}-10^{\text {th }}$ centuries in the Carpathian Basin. 299-306. Cluj-Napoca

KoczTUR É. 1964: Somogymegye régészeti leletkatasztere. - Régészeti Füzetek Serie II. 13. Budapest
LÁszLó GY. 1940: Avar kori pásztorkészségeink (Zu den Beigaben der Gräber von Awarischen Hirten). - Archaeologiai Értesítő III/1: 91-98.

LÁszLó GY. 1941: Adatok az avarság néprajzához II. (Contributi all' etnografia degli avari). Archaeologiai Értesítő III/2: 175-204.

PÁszTOR A. 2003: A székkutas-kápolnadűlői avar kori temető gyöngyleletei (Die Perlen des awarenzeitlichen Gräberfeldes von SzékkutasKápolnadűlő). - In: Bende Lívia - Lőrinczy Gábor (Szerk.): A székkutas-kápolnadülői avar temető. Szeged, 2003. 331-370.

RÁcz Zs. 1999: A madaras-téglavetői avar temető (Kőhegyi Mihály ásatása 1959-62). (Das Awarische Gräberfeld von Madaras-Téglavetö - Ausgrabungen von Mihály Köhegyi 1959-62). - A Móra Ferenc Múzeum Évkönyve - Studia Archaeologica 5: 347-396.

ScHMID, M. M. E. 2015: Das Gräberfeld von Rákóczifalva in Zentralungarn und die Chronologie des spätawarenzeitlichen Fundmaterial. Bonn

SZALONTAI Cs. 1995: A késő avar kori liliomos övveretek (Die spätawarenzeitliche mit Lilien verzierte Gürtebeschläge). - Somogyi Múzeumok Közleményei 11: 127-143.

SZALONTAI Cs. 2003: A székkutas-kápolnadülöi avar kori temető öveinek elemzése (Die Analyse der Gürtel des Awarenzeitlichen Gräberfeldes von Székkutas-Kápolnadülő). - In: Bende Lívia Lőrinczy Gábor (Szerk.): A székkutas-kápolnadűlői avar temető. Szeged, 2003. 371-412

SzÖKE B. M. 1992: Die Beziehungen zwischen dem Ostalpenraum und Westungarn in der ersten Hälfte des 9. Jahrhunderts (Frauentracht). - In: Daim F. (Hrsg.): Awarenforschungen. 841-968. Wien

SzÖKE B. M. 2008: Veränderungen in der Struktur des awarischen Gürtels. - Antaeus 29-30: 175-213.

ToMKA P. 1972: Adatok a Kisalföld avar kori népességének temetkezési szokásaihoz. (Beiträge zu den Besttanugsarten der Bevölkerung von Kisalföld in der Awarenzeit). - Arrabona 14: 25-75.

ToMKA P. 1975: Adatok a Kisalföld avar kori népességének temetkezési szokásaihoz II. (Beiträge zu den Besttanugsarten der Bevölkerung von Kisalföld in der Awarenzeit II.). - Arrabona 17: 5-90.

TOMKA P. 1977-78: Adatok a Kisalföld avar kori népességének temetkezési szokásaihoz III. (Angaben zum Bestatungsbrauchtum der Bevölkerung vom Kleinen Alföld in der Awarenzeit. III.). Arrabona 19-20: 17-108.

TÖRÖK GY. 1973: A sopronkőhidai IX. századi temető (The cemetery of Sopronköhida in the 9th century). Budapest

VöRös I. 1999: A halimbai késő avar kori temető állatcsontleletei (Tierknochenfunde des spätawarenzeitliche Gräberfeldes von Halimba). - Tisicum 11: 43-58. 


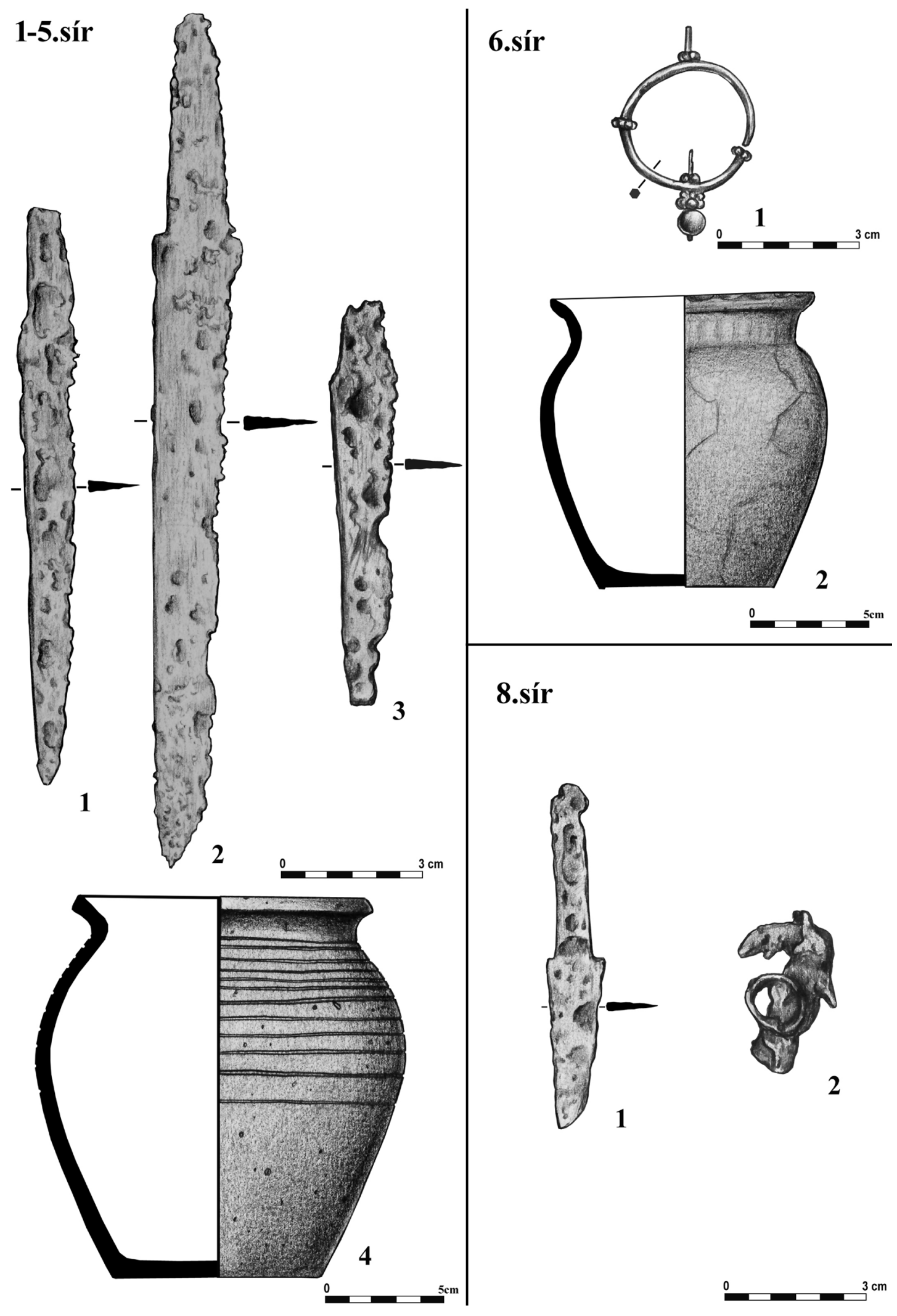

I. tábla. 1-6. sírok és 8. sír leletei 


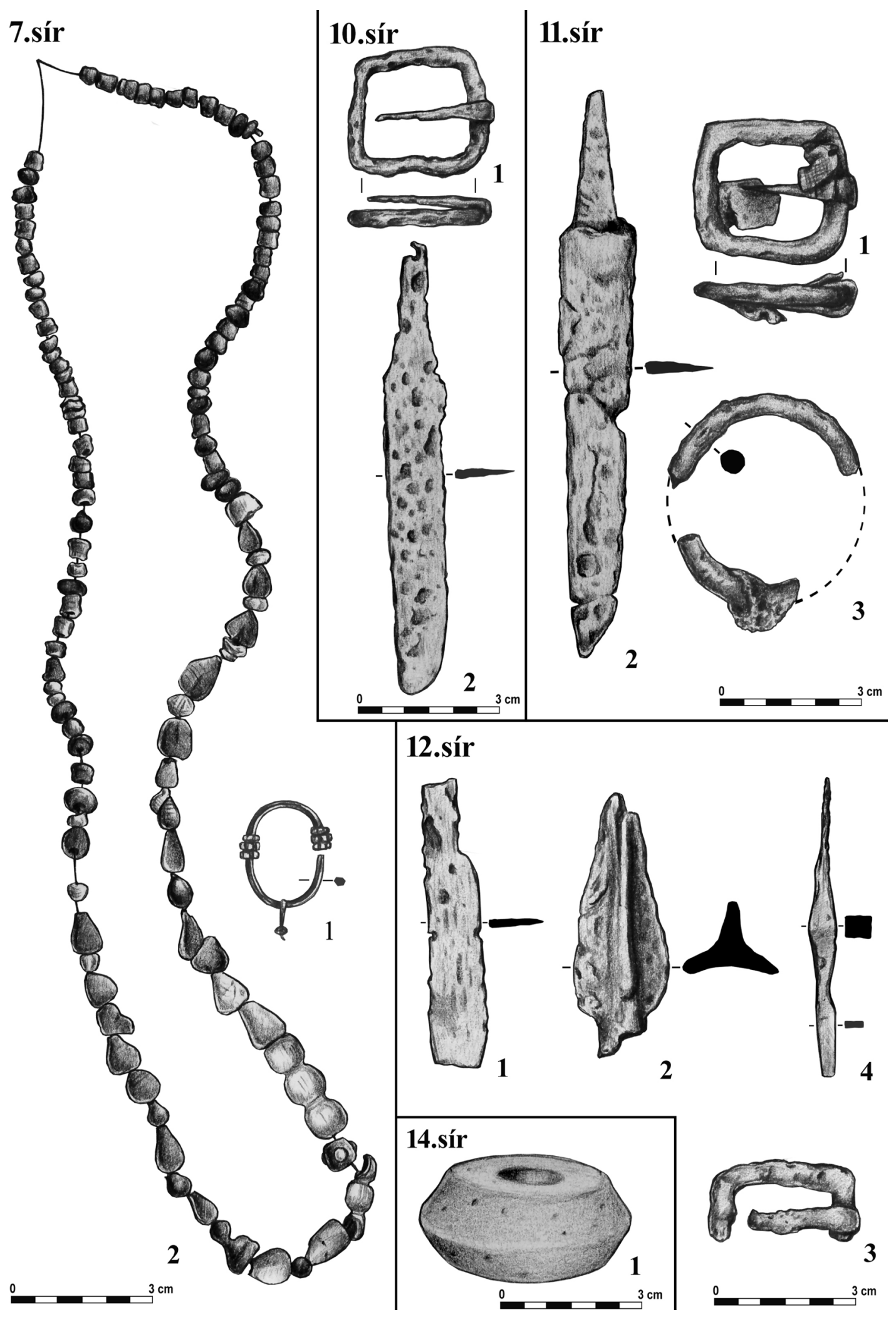

II. tábla. 7. sír és 10-14. sírok leletei 


\section{9.sír}

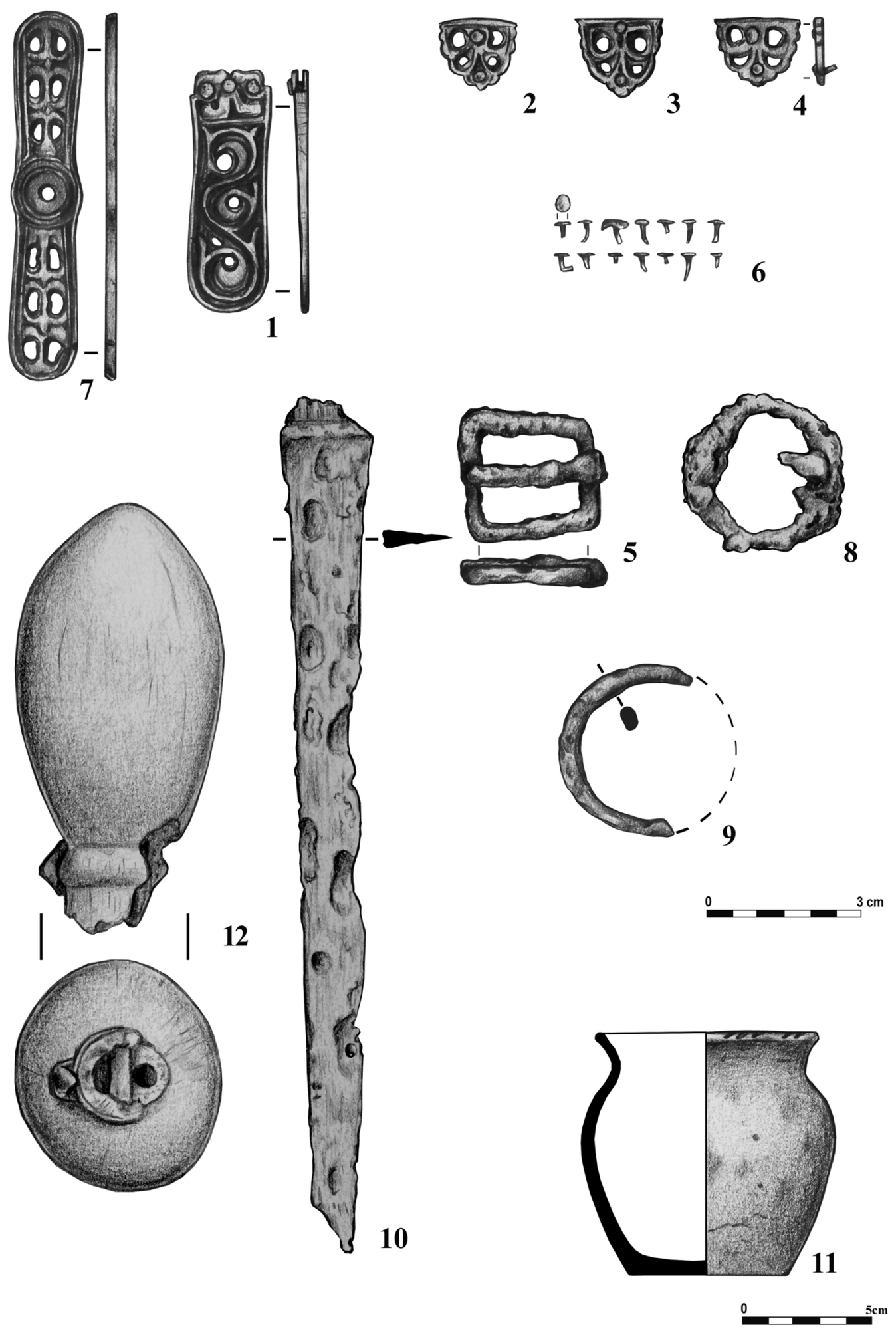

III. tábla. A 9. sír leletei 


\title{
The cemetery of the Late Avar Age in Csoma-Újtelep
}

\author{
MÁTYÁS HARAG
}

In 1956 Rezső Pusztai unearthed two groups of 15 inhumation graves of an Avar Age cemetery near Csoma (Somogy County). The groups of graves possibly laid in the northwestern and southeastern part of the cemetery.10 graves were destroyed by earthworks, but the other 5 were undisturbed. In the rectangular shaped graves the dead laid on their back with their arms mostly close to and in parallel to the body. The orientation of the tombs was nearly north-south, with an exception of three, nearly west-east orientation graves. The avarage depth of the graves was circa 200-210 $\mathrm{cm}$. In some cases, remains of a coffin were observed. The graves contained very poorly goods, first of all iron knives, iron buckles, pottery, an iron arrowhead, a biconical spindle-whorl and in some cases, animal bones. However, bronze belt mounts, a string of beads, pendants, and a whip-end made from an antler were also found. The northwestern group of graves can be dated to the first half of the $8^{\text {th }}$ century - beginning of the $9^{\text {th }}$ century, but in case of the southeastern group, we can only suppose that, the graves are from the $8^{\text {th }}$ century. 